Nigerian Journal Of Physiological Sciences 21 (1-2):31-35@Physiological Society Of Nigeria, 2006.

Available online/abstracted at http://www.biolineinternational.org.br/njps; www.ajol.info/journals.njps; www.cas.org

\title{
SAFETY AND HYPOGLYCAEMIC PROPERTIES OF AQUEOUS LEAF EXTRACT OF OCIMUM GRATISSIMUM IN STREPTOZOTOCIN INDUCED DIABETIC RATS.
}

\author{
U. G. EGESIE, A. B. ADELAIYE J. O. IBU ${ }^{2}$, and O. J. EGESIE ${ }^{1}$ \\ Departments of Human Physiology and Haematology ${ }^{1}$, Faculty of Medical Sciences, \\ University of Jos, Jos, Nigeria. \\ Department of Physiology', University of Calabar, Calabar, Nigeria.
}

Summary: The claim by Nigerian traditional herbal medicine practitioners that Ocimum gratissimum leaves have antidiabetic properties was investigated. Diabetes mellitus was induced with streptozotocin and graded doses of the aqueous leaf extract were administered orally to the experimentally diabetic rats for 28 days. Administration of the aqueous leaf extract caused a statistically significant reduction in plasma glucose level in streptozotocin induced diabetic rats. The extract appeared nontoxic as evidenced by normal serum levels of AST, ALT, ALP, TPT, ALB and bilirubin. These data appear to agree with claimed hypoglycaemic effects of Ocimum gratissimum.

Key Words: Ocimum gratissimum; Diabetes mellitus; Hypoglycaemia, Liver enzymes.

\section{Introduction}

Information is scanty on the use of Ocimum gratissimum as a medicinal plant. Available information reported Sofawora, (1982) was that the leaves of the plant are used by different tribes for different purposes in West Africa and Nigeria. This plant is a shrubbery herb in the family of Lamiaceae. It is used for the treatment of bacterial infections, fever, diarrhoea and as a spice. The various local names in Nigeria are as follows; Daidoya (Hausa); Nchuanu (Igbo); Efinrin (Yoruba). This plant has been recently claimed to be useful in the treatment of diabetes (personal communication from Dr. Alzija, traditional practitioner in the Department of Pharmacology, University of Jos-Nigeria). However, no scientific data are available on the efficacy and safety to support this claim. Although Aguiyi et al (2000) recently reported hypoglycaemic activities of Ocimum gratissimum in alloxan- induced diabetic rats, reports on its safety have not been documented.

The objective of the present study is directed towards evaluating the efficacy and safety of the plant as claimed by the herbal practitioners in the management of diabetes mellitus using streptozotocin induced diabetic rats.

\section{Materials and Methods}

Collection and identification of plant materials

The fresh leaves of the shrub were collected from the University of Jos. The leaves were identified and authenticated as Ocimum gratissimum leaves by Professor C. Akueshi, a plant taxonomist in the Department of Botany, Faculty of Natural Sciences, University of Jos, Nigeria. It was deposited as voucher specimen for future reference in the Department of Human Physiology, University of Jos.

\section{Preparation of Extract}

Fresh leaves of Ocimum gratissimum were air dried and ground into coarse powder. Eight hundred grams of the powdered leaves was stirred into $450 \mathrm{mls}$ of boiling distilled water. The boiling was allowed to continue for 5 minutes. It was then filtered through a fine sieve. The filtrate was cooled. The solution was centrifuged at $4000 \mathrm{rpm}$ for 10 minutes in a refrigerated centrifuge. The Supernatant was collected dried in vacuo using a rotary film evaporator. The residue was weighed and dissolved in a known volume of distilled water to give a concentration of $500 \mathrm{mg} / \mathrm{ml}$. It was kept frozen at $4^{\circ} \mathrm{C}$ and used in subsequent experiments. 


\section{Induction of Diabetes}

Diabetes mellitus was induced in rats by single intraperitoneal injection of $70 \mathrm{mg} / \mathrm{kg}$ streptozotocin supplied by Dr. J. C. Aguiyi of University of Jos, dissolved in $0.1 \mathrm{M}$ citrate buffer $\mathrm{pH}$ 4.5. Effectiveness of the drug was confirmed by the presence of high fasting plasma glucose level determined 24 and 48 hours after the injection. Graded doses of the aqueous extract were given to the rats. Body weight, fluid intake and food consumption patterns were monitored during the 28 day experimentation period.

\section{Treatment of Animals}

The experimental animals used for this study were locally bred male wistar strain rats from the animal house of University of Jos Nigeria. Rats of body weight $(150-200 \mathrm{~g})$ and 8 weeks old were used. The animals maintained under standard environmental conditions had free access to food (Grand cereal products, Jos , Nigeria) and water ad libitum. Eighteen groups of five rats each were distributed in cages and acclimatized for 48 hours. The groups were then treated as follows; Groups 1-3 were control groups receiving only water groups 4-6 were extract treated control rats receiving $250 \mathrm{mg} / \mathrm{kg}$ every 3 days groups 7-18 were streptozotocin induced diabetic rats dose $70 \mathrm{mg} / \mathrm{kg}$. Groups 7-9 received $500 \mathrm{mg} / \mathrm{kg}$ extract daily, $10-12$ received $1000 \mathrm{mg} / \mathrm{kg}$ extract daily, $13-15$ received $1500 \mathrm{mg} / \mathrm{kg}$ extract daily while $16-18$ received only water.

Rats were then housed in metabolic cages (Becker and Co GmBH animal cage model III F 75) to facilitate urine collection without faecal contamination. Following ether anaesthetization blood samples were collected at 1, 14 and 28 days by cardiac puncture for glucose estimation. Thereafter the animals were sacrificed.

\section{Toxicity testing (Time Course effects of selected doses).}

Four groups of twenty rats per group were acclimatized. Each group of rat received between $500-1500 \mathrm{mg} / \mathrm{kg}$ extract daily for 28 days. The control group of rats received water as their only source of fluid. Groups of rats were sacrificed by ether anaesthetization at days 0, 7, 14 and 28 after a extract administration and blood collected by cardiac puncture for estimation of ALT, AST ALP, Bilirubin, Albumin and Total protein.
Collection, preparation and analysis of blood samples

Blood was separately collected from each diabetic and non diabetic rat on the days stated above. Blood was allowed to clot and serum separated by centrifugation at $3500 \mathrm{rpm}$ for 10 minutes(JICA, Japan) for the Biochemical parameters.

The serum was assayed either immediately or stored at-20 ${ }^{\circ} \mathrm{C}$. Glucose concentration was determined by the glucose oxidase method of Trinder (1969). Alanine and aspartate transaminase (ALT, AST) levels were determined by the method of BergMeyer and Bernt, (1974) and alkaline phosphatase (ALP) by the procedure of King and kind (1954). Bilirubin was determined spectrophotometrically by the modified method of Malloy and Evelyn, (1937). Total protein was determined by the biuret method (Amstrong and Carr, 1960). Serum Albumin was determined by the dye bind method (Gowenlock, 1988).

Statistical Analysis of Data Data were analyzed using Students' t-test. P-value of 0.05 or less was considered to be significant. 6

\section{Results}

Induction of diabetes in the experimental rats was confirmed by the presence of high plasma glucose level as shown in Table 1. The difference between the experimental and control rats was statistically significant $(\mathrm{P}<0.05)$. No deaths were recorded during the experimental period. The effect of the extract on plasma glucose level of non-diabetic control, extract treated control and streptozotocin induced diabetic rats is shown in Table 2.

The levels of glucose in normal rats receiving the extract did not differ significantly from control rats without extract treatment. However, there was significant difference $(\mathrm{P}<$ 0.05 ) between the level of glucose in diabetic and normal rats and also between diabetic control rats and diabetic rats on the extract.

Increasing the concentration of the extract produced a dose and time dependent decrease in plasma glucose level over the 28-day period of administration of the extract. The values obtained for blood glucose in extract treated diabetic rats on day 14 and 28 were significantly lower $(\mathrm{P}<0.05)$ compared with diabetic control. The concentrations of the indices of toxicity determined by the estimation of ALT, AST, ALP, TPT, ALB and bilirubin were not significantly different $(\mathrm{P}>0.05)$ from the control (Table 3). 
Hypoglycaemic properties leaf extract of Ocimum gratissimum

Table 1: Serum glucose levels in Streptozotocin- induced diabetic rats $24 \mathrm{~h}$ and $48 \mathrm{~h}$ after induction

\begin{tabular}{lcc}
\hline \multicolumn{1}{c}{ Group } & 24h glucose $(\mathrm{mmol} / \mathrm{L})$ & 48h glucose $(\mathrm{mmol} / \mathrm{L})$ \\
\hline Non Diabetic(control) & $4.20 \pm 0.12$ & $4.60 \pm 0.11$ \\
Diabetic(test) & $8.40 \pm 0.11^{\mathrm{a}}$ & $8.60 \pm 0.42^{\mathrm{a}}$ \\
\hline
\end{tabular}

Mean \pm SEM for five determinations ${ }^{a} P<0.01$ Significantly higher in diabetic(test) compared to non diabetic rats(controls).

Table 2: Effect of Oral administration of aqueous extract of Ocimum gratissimum on plasma glucose level of non diabetic control, Extract treated control and streptozotocin induced diabetic rats on Day 1, 14 and 28 .

\begin{tabular}{|c|c|c|c|}
\hline \multirow[b]{2}{*}{ Groups } & \multirow{2}{*}{$\begin{array}{l}\text { Plasma glucose } \\
\text { Day } 1\end{array}$} & \multicolumn{2}{|c|}{ Concentration $(\mathrm{mmol} / \mathrm{L}) \quad \mathrm{n}=5)$} \\
\hline & & Day 14 & Day 28 \\
\hline Control & $4.40 \pm 0.11$ & $4.20 \pm 0.15$ & $4.40 \pm 0.12$ \\
\hline $\begin{array}{l}\text { Non diabetic }+250 \mathrm{mg} / \mathrm{kg} \\
\text { extract every } 3 \text { days }\end{array}$ & $4.67 \pm 0.24$ & $4.93 \pm 0.24$ & $4.87 \pm 0.1$ \\
\hline Diabetic control & $8.60 \pm 0.42^{\mathrm{a}}$ & $8.27 \pm 0.18^{\mathrm{a}}$ & $8.87 \pm 0.35^{\mathrm{a}}$ \\
\hline $\begin{array}{l}\text { Diabetic rats }+500 \mathrm{mg} / \mathrm{kg} \\
\text { extract }\end{array}$ & $8.60 \pm 0.12^{\mathrm{a}}$ & $6.36 \pm 0.27^{\mathrm{a}, \mathrm{b}}$ & $5.33 \pm 0.18^{\mathrm{a}, \mathrm{b}}$ \\
\hline $\begin{array}{l}\text { Diabetic rats }+1000 \mathrm{mg} / \mathrm{kg} \\
\text { extract }\end{array}$ & $8.20 \pm 0.11^{a}$ & $5.30 \pm 0.17^{\mathrm{a}, \mathrm{b}}$ & $5.30 \pm 0.15^{\mathrm{a}, \mathrm{b}}$ \\
\hline $\begin{array}{l}\text { Diabetic rats }+1500 \mathrm{mg} / \mathrm{kg} \\
\text { extract }\end{array}$ & $8.66 \pm 0.41^{a}$ & $5.60 \pm 0.12^{\mathrm{a}, \mathrm{b}}$ & $5.0 \pm 0.12^{\mathrm{a}, \mathrm{b}}$ \\
\hline
\end{tabular}

Mean \pm SEM for five determinations. $.^{a} P<0.05$ Significantly higher compared with normal rats ${ }^{b} P<0.05$ significant as compared with diabetic control rats

Table 3: Effect of oral administration of (varying doses) of Ocimum gratissimum on Serum levels of ALP, ALT, AST,TPT, ALB, TBL on normal rats

\begin{tabular}{|c|c|c|c|c|c|c|c|}
\hline \multicolumn{2}{|c|}{$\begin{array}{c}\text { Day Dose } \\
(\mathrm{mg} / \mathrm{Kg})\end{array}$} & \multicolumn{6}{|c|}{ IU/L $\mathrm{g} / \mathrm{L} \mathrm{mmol} / \mathrm{L}$} \\
\hline & ALP & ALT & AST & TPT (g/L) & ALB (g/L) & TB(umol/L) & $1.9 \pm 0.06$ \\
\hline \multirow{3}{*}{0} & 0 & $218.7 \pm 9.40$ & $71.3 \pm 0.67$ & $272.0 \pm 1.15$ & $66.0 \pm 0.00$ & $33.0 \pm 0.58$ & $2.0 \pm 0.00$ \\
\hline & 500 & $218.7 \pm 9.40$ & $70.7 \pm 0.67$ & $271.6 \pm 0.88$ & $52.0 \pm 0.00$ & $32.7 \pm 1.45$ & $2.1 \pm 0.45$ \\
\hline & 1000 & $204.3 \pm 29.47$ & $72.0 \pm 1.15$ & $123.3 \pm 3.33$ & $19.0 \pm 0.00$ & $32.6 \pm 1.76$ & $2.0 \pm 0.28$ \\
\hline \multirow{5}{*}{7} & 1500 & $214.3 \pm 7.21$ & $72.7 \pm 2.67$ & $266.3 \pm 9.13$ & $41.0 \pm 0.00$ & $32 . .3 \pm 7.88$ & $1.8 \pm 0.14$ \\
\hline & 0 & $251.0 \pm 1.00$ & $81.7 \pm 0.88$ & $262.7 \pm 8.19$ & $55.0 \pm 2.88$ & $39.0 \pm .2 .08$ & $1.9 \pm 0.06$ \\
\hline & 500 & $54.3 \pm 16.69$ & $283.0 \pm 7.00$ & $256.7 \pm 21.85$ & $55.0 \pm 2.88$ & $38.3 \pm 1.67$ & $1.9 \pm 0.06$ \\
\hline & 1000 & $250.0 \pm 17.32$ & $84.0 \pm 2.64$ & $260.3 \pm 20.49$ & $56.7 \pm 2.96$ & $36.7 \pm 2.40$ & $2.0 \pm 0.08$ \\
\hline & 1500 & $250.0 \pm 5.77$ & $81.7 \pm 1.67$ & $253.3 \pm 17.63$ & $54.3 \pm 2.84$ & $39.8 \pm .0 .67$ & $2.1 \pm 0.05$ \\
\hline \multirow{3}{*}{14} & 0 & $187.7 \pm 20.21$ & $74.0 \pm 7.02$ & $301.3 \pm 12.34$ & $52.3 \pm 1.45$ & $33.0 \pm 1.52$ & $2.1 \pm 0.05$ \\
\hline & 500 & $185.0 \pm 19.13$ & $75.7 \pm 6.69$ & $326.0 \pm 41.10$ & $51.3 \pm 0.88$ & $31.7 \pm 0.88$ & $2.0 \pm 0.00$ \\
\hline & 1000 & $189.7 \pm 17.32$ & $73.0 \pm 6.50$ & $297.6 \pm 9.59$ & $52.7 \pm 1.20$ & $32.0 \pm .1 .45$ & $2.2 \pm 0.08$ \\
\hline \multirow{5}{*}{28} & 1500 & $186.0 \pm 18.55$ & $70 . .7 \pm 5.20$ & $306.0 \pm 8.72$ & $52.3 \pm 1.45$ & $32.3 \pm 1.45$ & 2. $0 \pm 0.03$ \\
\hline & 0 & $257.0 \pm 2.08$ & $74.7 \pm 4.37$ & $246.0 \pm 16.00$ & $550 \pm 3.51$ & $36.7 \pm 1.20$ & $1.8 \pm 0.0$ \\
\hline & 500 & 244. \pm 12.7 & $64.7 \pm 2.90$ & $244.0 \pm 14.00$ & $55.6 \pm 3.28$ & $34.7 \pm 0.33$ & $2.0 \pm 0.13$ \\
\hline & 1000 & $211.3 \pm 22.04$ & $66.8 \pm 4.05$ & $241.7 \pm 16.29$ & $55.0 \pm 3.51$ & $35.7 \pm .1 .20$ & $1.7 \pm 0.20$ \\
\hline & 1500 & $257.7 \pm 17.57$ & $75.3 \pm 5.69$ & $239.7 \pm 15.38$ & $50.3 \pm 1.20$ & $39.0 \pm 0.57$ & \\
\hline
\end{tabular}

Serum (Levels (Mean \pm SEM, $n=5) \quad P<0.05$ Comparison of experimental and control group 


\section{Discussion}

Ociumum gratissimum is widely distributed throughout Central America, West African coast and has been used in Trinidad and Tobago and in Nigeria for the treatment of various ailments including diabetes mellitus (Bailey and Day, 1989; Aguiyi et al, 2000) This work reports the results of preliminary investigation into the efficacy of the use of $O$. gratissimum in treating diabetes mellitus as well as the assessment of safety of the leaf extract using rats. The aqueous extract did not exert significant side effect on the vital organs of the body as determined by biochemical indices (Dossing and Anderson, 1986).

The results of preliminary investigation of the hypoglycaemic property of the plant showed that the plant is an effective antidiabetic agent. The administration of graded doses of the aqueous leaf extract produced a statistically significant decrease $(\mathrm{P}<0.05)$ in serum glucose concentration when compared with diabetic control rats and normal control rats.

Twenty eight day administration of the extract to non diabetic rats did not produce any significant difference in the plasma glucose concentration of non diabetic extract treated rats compared with control. The mechanism of the hypoglycaemic effects of the aqueous extract of this plant is not clear at the moment. However, reports are available to show that antidiabetic plants may affect circulating insulin level (Lamela et al, 1985). Studies have shown that free radicals can cause disruption in insulin action and mitigate glucose tolerance states (Ford, 1999). It is also possible that treatment with $O$. gratissimum could be facilitating utilization of glucose by peripheral tissues. This mechanism has been observed in the use of infusion of African mistletoe (Obatomi et al, 1994) and aqueous bark extract of Ceiba pentandra (Ladeji et al, 2003) in the treatment of diabetes mellitus. The mechanism of action was however, not investigated owing to technical reasons.

The statistically significant high glucose level observed in plasma of streptozotocin induced diabetic rats indicate establishment of a diabetic state. However, in streptozotocininduced diabetic rats, administration of graded doses of the aqueous extract produced a gradual decrease in plasma glucose levels from 1 to 14 and 28 days. The gradual decrease in plasma glucose levels may be due to the fact that $O$. gratissimum could be facilitating utilization of glucose by peripheral tissue. It is important to note that the plant extract contains flavonoids and other phytochemical constituents believed to be responsible for its hypoglycaemic property (Oladele et al, 1995). The extract also contains major mineral elements e.g. Calcium, chloride, manganese, magnesium, zinc and potassium which might also play a contributory role in enhancing medicinal properties such as the hypoglycaemic property (Chen et al, 1995).

The comparable values for indices of toxicity in the cell (AST, ALT, ALP, TPT, ALB and Bilirubin) between diabetic and non-diabetic extract treated rats suggests that the extract may not be toxic at least to the liver at the concentration employed (Dossing and Anderson 1986).

We conclude that since the aqueous leave extract of $O$. gratissimum given orally for a period of 28 days produced a decreased plasma glucose level and it does not appear to be toxic, the plant has a hypoglycacmic effect and may be safe when taken orally if the results obtained with rats are applicable to man.

\section{Acknowledgements}

The authors are grateful to the Department of Chemical Pathology of Jos University Teaching Hospital for analysis of the blood samples.

\section{Reference}

Aguiyi, J. C. , Obi, C. I. , Gyang, S. S., Igweh, A. C. (2000). Hypoglycaemic activity of Ocimum gratissimum in rats. Fitoterapia .71 (4): 444-6.

Armstrong, W. D. and Carr, C. W. (1960): Physiological Chemistry Laboratory Directions. Minneapolis; Burgress Publishing Company, pp. 73-4.

Bailey, C. J. and Day, C. (1989). Traditional Plant medicines as treatment for diabetes. Diabetes care 12:553-564.

Berg Meyer, H. V. and Bernt E. (1974). Spectrophotometric determination of amino acid transferases. In: Bergmeyerand, H. U. and Bernt E. (Eds). Methods of enzymatic Analyses Academic Press, Orlando, FL, pp. 320-401.

Chen, M. D., Lin, P. Y.; Tsou, C. T.; Wang, J. J. and Lin, W. H. (1995). Selected Metal Status in Patients with non insulindependent diabetes Mellitus. Biology of Trace Element Research. 50(2): 119 - 124.

Dossing, M. and Anderson, P. B. (1986). Diagnosis of acute drug induced liver injury. 
Usefulness of Clinico pathological patterns and Biochemical indices. Med. Toxicolol.. 1:77-82.

Ford, R. U. (1999). Diabetes mellitus and serum carotenoids findings from the third National and Nutrition Examination Survey. American Journal of Epidemiology 149, 168 $-176$.

Gowenlock, A. H. (1988). Varley's Practical Clinical Biochemistry. Sixth edition. London; Heineman Medical Books, 407-20, 499-504, 528, 744-6.

King, E. J., and Kind P. N. (1954). Determination of acid and alkaline phosphatases activities using disodium phenyl phosphate. Journal of Clinical Pathology. 7, 322-330.

Ladeji, O. Omekarah, I.; Solomon, M (2003). Hypoglycemic properties of aqueous bark extract of Ceiba pentandra in streptozotocininduced diabetic rats. Journal of Ethnopharmamacology. 84, 139 - 142.

Lamela, M., Gato, A., Calleja, J. M. (1985). Effects of lythrum sahcaria in normoglycaemic rats. J. Ethnopharmacol. $14,83-91$.

Malloy, H. T., and Evelyn, K. A. (1937). The determination of bilirubin with photoelectric colorimeter J.Biol.l Chemistry. 119, 481-490.

Obatomi, D. K., Bikimo, E., and Temple, B. J. (1994). Antidiabetic properties of the African mistletoe in streptozotocin induced diabetic rats. Journal of Ethnopharmacology. 43:13-17.

Sofowora, A. (1982). Medicinal plants and Traditional Medicine in Africa John Wiley and Sons Ltd., Chichester, England. pp.142145.

Trinder, P. (1969). Determination of blood glucose using 4- amino phenazone as Oxygen acceptor. Journal of Clinical Pathology. 22:246-248.

Received: 15/9/06

Accepted: 15/11/06 